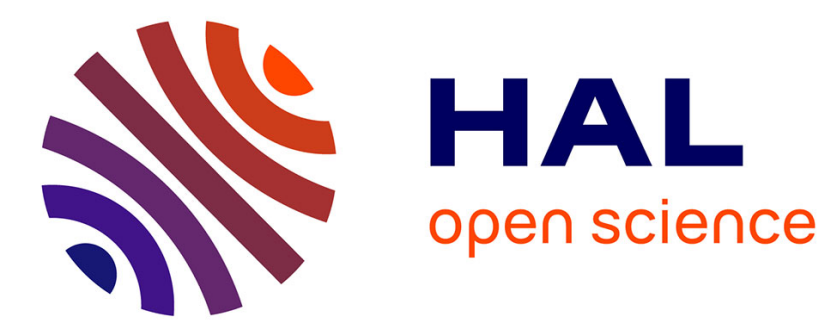

\title{
Synchronous-scan fluorescence of algal cells for toxicity assessment of heavy metals and herbicides.
}

\author{
Hanh Nguyen-Ngoc, Claude Durrieu, Canh Tran-Minh
}

\section{To cite this version:}

Hanh Nguyen-Ngoc, Claude Durrieu, Canh Tran-Minh. Synchronous-scan fluorescence of algal cells for toxicity assessment of heavy metals and herbicides.. Ecotoxicology and Environmental Safety, 2009, 72 (2), pp.316-20. 10.1016/j.ecoenv.2008.04.016 . hal-00410275

\section{HAL Id: hal-00410275 \\ https://hal.science/hal-00410275}

Submitted on 19 Aug 2009

HAL is a multi-disciplinary open access archive for the deposit and dissemination of scientific research documents, whether they are published or not. The documents may come from teaching and research institutions in France or abroad, or from public or private research centers.
L'archive ouverte pluridisciplinaire HAL, est destinée au dépôt et à la diffusion de documents scientifiques de niveau recherche, publiés ou non, émanant des établissements d'enseignement et de recherche français ou étrangers, des laboratoires publics ou privés. 


\title{
Synchronous-scan fluorescence of algal cells for toxicity assessment of heavy metals and herbicides
}

NGUYen-NGoC (1), H. ; DURRIEU ${ }^{\left(2^{*}\right)}$, C. ; Tran-Minh(3), C.

(1) University of Technology HCM, 268 rue Ly Thuong Kiet, Ho Chi Minh, Viet Nam

(2) Ecole Nationale des Travaux Publics de l'Etat, Laboratoire des Sciences de l'Environnement (LSE), Rue Maurice Audin, 69518 Vaulx-en-Velin Cédex, France

(3) Département PMMC (Poudres et Matériaux Multi Composants), Centre SPIN. Ecole Nationale Supérieure des Mines de Saint-Etienne. 158, Cours Fauriel. 42023 SaintEtienne Cedex 2.

(*) durrieu@entpe.fr

Keywords:

Synchronous-scan spectrometry; "Chlorella vulgaris"; Vegetal cells; Fluorescence; Immobilized algae; Silica matrix; Sol-gel; Toxicity assessment; Heavy metals; Herbicides

\begin{abstract}
Synchronous-scan spectrofluorometry was applied to Chlorella vulgaris cells to assess the toxicity of heavy metals and herbicides in water. Simultaneous scan of both the excitation and emission spectra was done at a constant wavelength difference $\Delta \lambda(20-140 \mathrm{~nm})$ between the emission and excitation wavelengths in the range of $420-700 \mathrm{~nm}$ emission, where a peak of fluorescence was observed. Its position depends on $\Delta \lambda$. Fluorescence measurements were conducted with algal cells in suspension in water and immobilized in a translucent silica matrix. The influence of toxic chemicals was tested with cadmium as a heavy metal and with atrazine, diuron, DNOC and paraquat as herbicides. The toxic effect of those chemicals mainly results in a quenching of algal cells fluorescence by reducing their photosynthetic activity.
\end{abstract}

\section{Introduction}

Deterioration of the aquatic environment and groundwater contamination are usually attributed to domestic sewage, industrial effluents and agricultural products leaching from cultivated areas. Heavy metals and herbicides are among the most toxic compounds found in ground water. Cadmium is an extremely toxic metal commonly present in industrial workplaces, particularly where any ore is being processed or smelted. It is used extensively in electroplating, also found in some industrial paints and may represent a hazard when sprayed. It is also present in the manufacture of some types of batteries. Herbicides are widely used in agriculture and in landscape management, and can then be transported via surface run-off to contaminate distant water sources. Some of the herbicides in use are known to be mutagenic, carcinogenic or teratogenic. Sensitive techniques using sophisticated and expensive equipment such as gas/liquid chromatography and mass spectrometry are currently performed for their detection and monitoring. Assessment of human exposure to these toxicants through biological monitoring offers another method to evaluate the magnitude of their potential health risks. A number of bioassays have been reported for the assessment of heavy metals and herbicides toxicity. They include bacterial tests using Photobacterium phosphoreum (Tomulka et al., 1993), ATP bioassays (Kwan, 1989), immunoassays (Von Emon and Lopez Avilla, 1992), fish and daphnia mobility tests (GardTerech and Palla, 1986), enzyme assays (Cowell et al., 1995) and algal growth tests (AbouWaly et al., 1991). Algae are essential in aquatic ecosystems since they provide oxygen and organic substances to other life forms. Chemical action of pollutants can affect their 
photosynthetic activity, resulting in oxygen depletion and a decrease in aquatic biodiversity. Therefore, algae can serve as biological monitors of water quality and as biological indicators in the assessment of environmental impact of pollutants. For algal tests, microalgae in suspension have so far been used, and fluorescence detection is often preferred over growth measurement because of its higher sensitivity (Samson and Popovic, 1988; Conrad et al., 1993; Juneau et al., 2002; Eullaffroy and Vernet, 2003; Fai et al., 2007). Fluorescence spectroscopy is one of the most promising techniques of increasing importance for complex analysis (Oldham et al., 2000). Synchronous-scan spectroscopy has been used to characterize water-soluble organic compounds in atmospheric aerosols (Duarte et al., 2004), to study the interaction of Chlorella vulgaris with Fe(III) and humic acid (Liu et al., 2005; Deng et al., 2005), for classification of edible oils (Sikorska et al., 2005) and for determination of proteins (Wang et al., 2004) and human serum albumin (Hou et al., 2007). Among the benefits of synchronous-scan-fluorescence spectroscopy are its enhanced selectivity and its high sensitivity to a wide array of analytes, and no reagents are required in the case of algal cells. The aim of this paper is not to investigate the mechanism of algae photosynthesis and their photosystems which require specific techniques such as pulse amplitude-modulated (PAM) fluorometry (Jones et al., 1999), and fast repetition rate (FRR) fluorometry (Lombardi et al., 2000). In this study, synchronous-scan spectrofluorometry was applied to C. vulgaris cells for analytical applications and in order to assess the toxicity of heavy metals and herbicides in water.

\section{Materials and methods}

\section{Culture of $C$. vulgaris}

The C. vulgaris strain (CCAP 211/12) was purchased from the culture collection of algae and protozoa at Cumbria, United Kingdom. The axenic algal strain was grown in the culture medium Lefebvre-Czarda and under conditions described by the International Organization for Standardization ISO 8692 (2002). Precultures were carried out at ambient temperature. Cultures started at $22{ }^{\circ} \mathrm{C}$ with a cell concentration of $10^{4} / \mathrm{mL}$ under air bubbling $(6 \mathrm{o} \mathrm{L} / \mathrm{h})$ and periodic illumination ( $16 \mathrm{~h}$ photoperiod under $50 \mu \mathrm{E} / \mathrm{m}^{2} \mathrm{~s}$ with cool white fluorescent tubes).

\section{Choice of toxic chemicals}

Cadmium (Cd II) was chosen as an example of a toxic metal for the toxicity test. It was used in the form $\left[\mathrm{Cd}\left(\mathrm{NO}_{3}\right)_{2}, \cdot 4 \mathrm{H}_{2} \mathrm{O}\right]$ and purchased from Merck. The following herbicides were tested because they are commonly used for their global or specific activity in cereal culture. They include DNOC [4,6-dinitro-o-cresol], paraquat [1,1'-dimethyl-4,4'-bipyridiniumdichloride hydrate], diuron (DCMU) [3(3,4-dichlorophenyl)1,1 dimethylurea], and atrazine [2ethylamino-4-chloro-6-isopropyl amino-1,3,5 triazine]. Paraquat and DNOC are known as inhibitors of photosystem I (PSII) and diuron and atrazine are inhibitors of photosystem II (PSII) in plants. All herbicides were of analytical grade (Pestanal) and were purchased from Riedel-de-Haen. Herbicides were prepared in Milli-Q water (Millipore) to obtain stock solutions which are stored in darkness at $4{ }^{\circ} \mathrm{C}$ for 7 days. All test solutions were diluted in Milli-Q water immediately before use.

\section{Cell entrapment}

Sodium silicate (0.4 M, $4 \mathrm{~mL}$ ) and LUDOX (8.5 M, $4 \mathrm{~mL}$ ) solutions were thoroughly mixed to obtain a homogeneous silica solution. An $\mathrm{HCl}, 4 \mathrm{M}$ solution was then added drop by drop until $\mathrm{pH} 7$ was reached to induce the gelation process. An algal solution at various concentrations was immediately introduced under stirring and the resulting solution was cast in cuvettes to produce silica matrixes containing algal cells. Gelation was obtained in a few minutes. To assess its toxicity to algal cells, a heavy metal or herbicide at different 
concentrations was added to the algal solution just before the gelation process. All experiments were performed at ambient temperature.

\section{Synchronous-scan spectrofluorometry}

Synchronous-scan fluorometry was performed with a Spex Fluorolog 2 spectrofluorometer from Jobin-Yvon equipped with a microcomputer for data recording. Fluorescence intensity was recorded, while excitation and emission wavelengths were synchronously scanned with two monochromators. Assays were carried out in cuvettes with algal cells either in solution or entrapped in a silica matrix. Illumination was obtained with an excitation/emission slit of 10/10 nm under a PMT voltage of $950 \mathrm{~V}$ : these parameters ensured reproducible conditions to induce fluorescence. Various $\Delta \lambda$ ranging from 20 to $140 \mathrm{~nm}$ were maintained between excitation and emission wavelengths during synchronous scan which was conducted with an increment of $0.5 \mathrm{~nm}$ and an integration time of $0.1 \mathrm{~s}$. Fluorescence intensity is expressed in arbitrary unit (au). All experiments were done in triplicate.

\section{Results}

Synchronous-scan spectroscopy of $C$. vulgaris in an aqueous suspension

Synchronous-scan spectroscopy is a technique wherein simultaneous scan of both the excitation and emission spectra is done at a constant difference between the emission and excitation wavelengths, $\Delta \lambda=\lambda_{\mathrm{em}}-\lambda_{\mathrm{ex}}$. This technique was first carried out with algal cells in suspension in water and the fluorescence emission recorded in the range of $420-700 \mathrm{~nm}$, where a peak was observed (Fig. 1). The position of the peak depends on the wavelength difference $\Delta \lambda$ : the greater the $\Delta \lambda$, the lower the fluorescence emission wavelength corresponding to the peak. To $\Delta \lambda=20 \mathrm{~nm}$ corresponds a peak at $670 \mathrm{~nm}$, while to $\Delta \lambda=140 \mathrm{~nm}$ corresponds the peak located at $540 \mathrm{~nm}$. The highest emission peak corresponds to $\Delta \lambda=20 \mathrm{~nm}$, which is thus chosen for toxicity assessment. When cadmium is added to the algal suspension, the peak height is reduced. An important reduction of the peak is observed at $670 \mathrm{~nm}$ with $16 \mathrm{ppb}$ cadmium after $1 \mathrm{~h}$ incubation time. These conditions are used to obtain the algal cells spectra in the presence of cadmium.

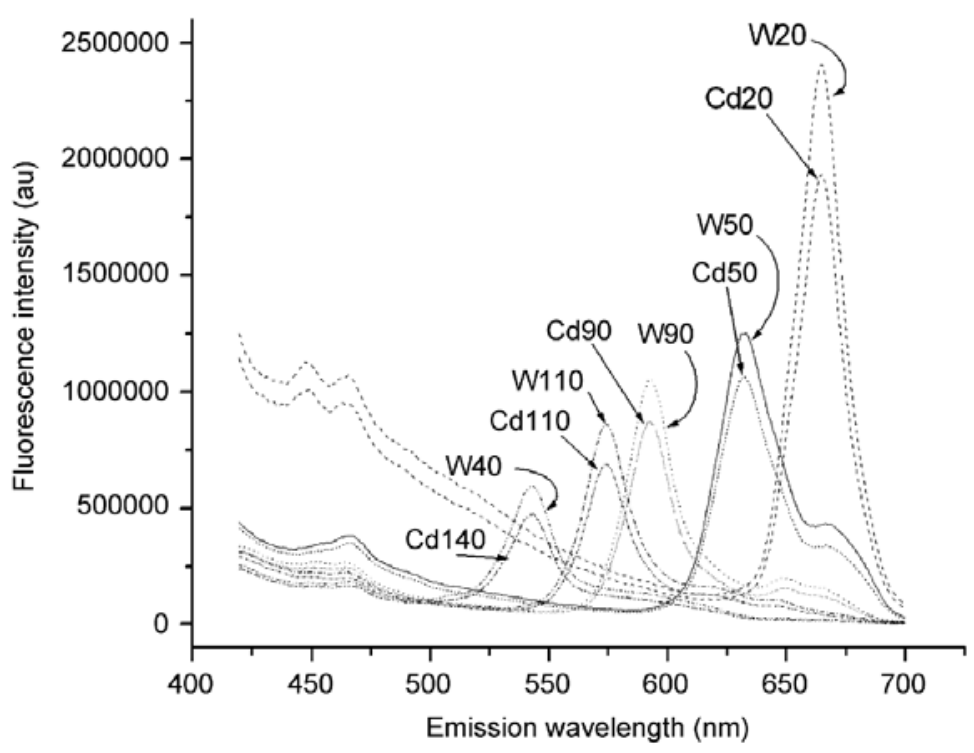

Fig 1: Synchronous fluorescence spectroscopy of "Chlorella vulgaris" cells in suspension in water $\left(35 \times 10^{6}\right.$ cells $\left./ \mathrm{mL}, \mathrm{pH} 7\right)$ in the absence (W) and in the presence $(\mathrm{Cd})$ of cadmium (16 ppb) using various wavelength differences $(\Delta \lambda=20-140 \mathrm{~nm})$ between excitation and emission wavelengths. Fluorescence intensity is expressed in arbitrary unit (au). 
Synchronous fluorescence spectroscopy of $C$. vulgaris immobilized in a translucent matrix

Fluorescence measurements are not reliable when samples vary in homogeneity. The use of microalgae suspensions presents the problem of maintaining a homogeneous sample (Cosgrove and Borowitzka, 2006). Immobilization in a silica matrix provides a simple solution to this problem. However, immobilization of algal cells by physical entrapment may affect their physicochemical properties (Bozeman et al., 1989). Therefore, it is necessary to compare their behavior before and after entrapment. Fig. 2 shows that using $\Delta \lambda=20 \mathrm{~nm}$ nearly the same peak at $670 \mathrm{~nm}$ is found for both cells in suspension and immobilized in the silica matrix. The peak heights are also very similar, while their intensities become quite different for lower wavelengths. Under these conditions, synchronous-scan fluorescence can be applied to immobilized algal cells for chemical toxicity assessment. In addition, entrapped algal cells can be used as active membranes for biosensors (Naessens et al., 2000).

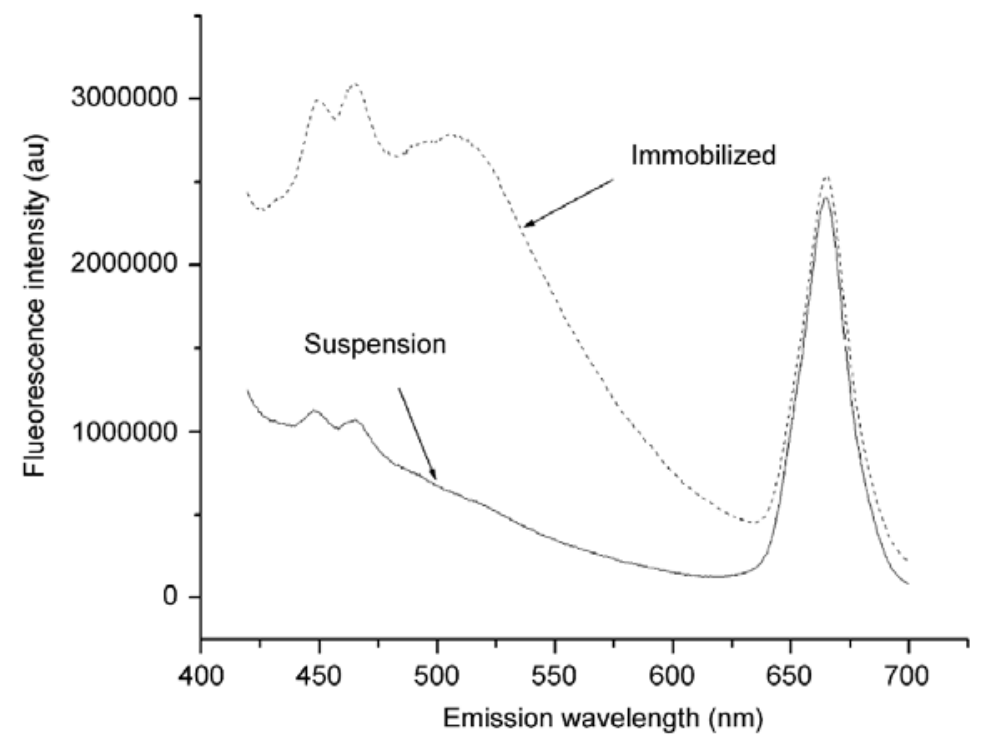

Fig 2: Synchronous fluorescence spectroscopy of "C. vulgaris" cells $\left(35^{\times 10^{6}}\right.$ cells $\left./ \mathrm{mL}\right)$ in suspension in water ( $\mathrm{pH}$ 7) and immobilized in a silica gel using $\Delta \lambda=20 \mathrm{~nm}$ between excitation and emission wavelengths. Fluorescence intensity is expressed in arbitrary unit (au).

\section{Effect of metal concentration}

The photosynthetic activity of algal cells is affected by heavy metals at very low concentrations. Fig. 3 shows that synchronous fluorometry is a sensitive method for their toxicity assessment, since the fluorescence quenching efficiency $I_{0} / I$ increases with metal concentration in the dynamic range. The quenching efficiency is defined as the ratio $I_{\mathrm{o}} / I$ of the fluorescence $I_{0}$ in the absence to the fluorescence $I$ in the presence of toxicant. Determination of cadmium is possible within the concentration range $0-150 \mathrm{ppb}$ from a calibration curve. The toxic effect of heavy metal also depends upon the time the metal is in contact with the algal cells. This incubation time from 1 to 7 days increases the fluorescencequenching efficiency of cadmium as indicated in the figure.

\section{Effect of herbicides concentration}

Vegetal cells are the main target of herbicides, and the fluorescence of algal cells is affected by the presence of atrazine, diuron, DNOC and paraquat (Fig. 4). Fluorescence emission at $670 \mathrm{~nm}$ with a scan wavelength difference $\Delta \lambda=20 \mathrm{~nm}$ decreases quite regularly with DNOC and paraquat concentrations. 


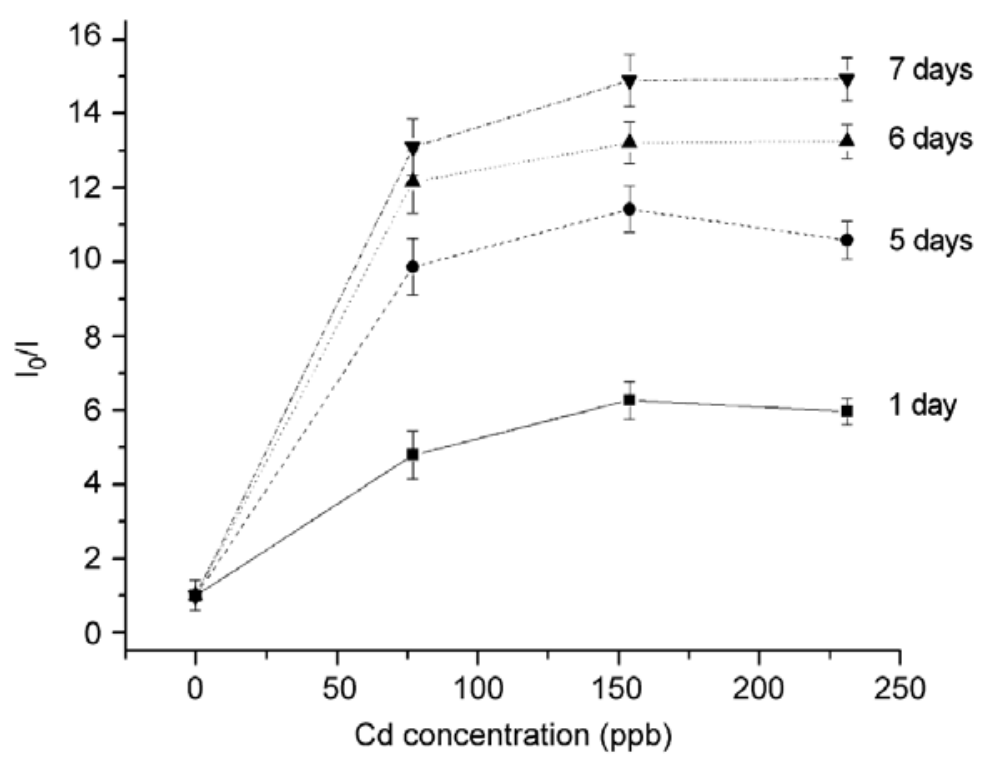

Fig 3: Synchronous fluorescence quenching of immobilized "C. vulgaris" cells $\left(35 \times 10^{6}\right.$ cells $\left./ \mathrm{mL}\right)$ by cadmium ions as a function of Cd concentration after various periods of incubation time (1-7 days), using $\Delta \lambda=20 \mathrm{~nm}$ and the fluorescence peak at $670 \mathrm{~nm}$.

However, for atrazine and diuron the fluorescence increases when the concentrations are below $1 \mu \mathrm{g} / \mathrm{L}$ and decreases for higher concentrations. This behavior could be ascribed to their specific mode of action on PS I and II.

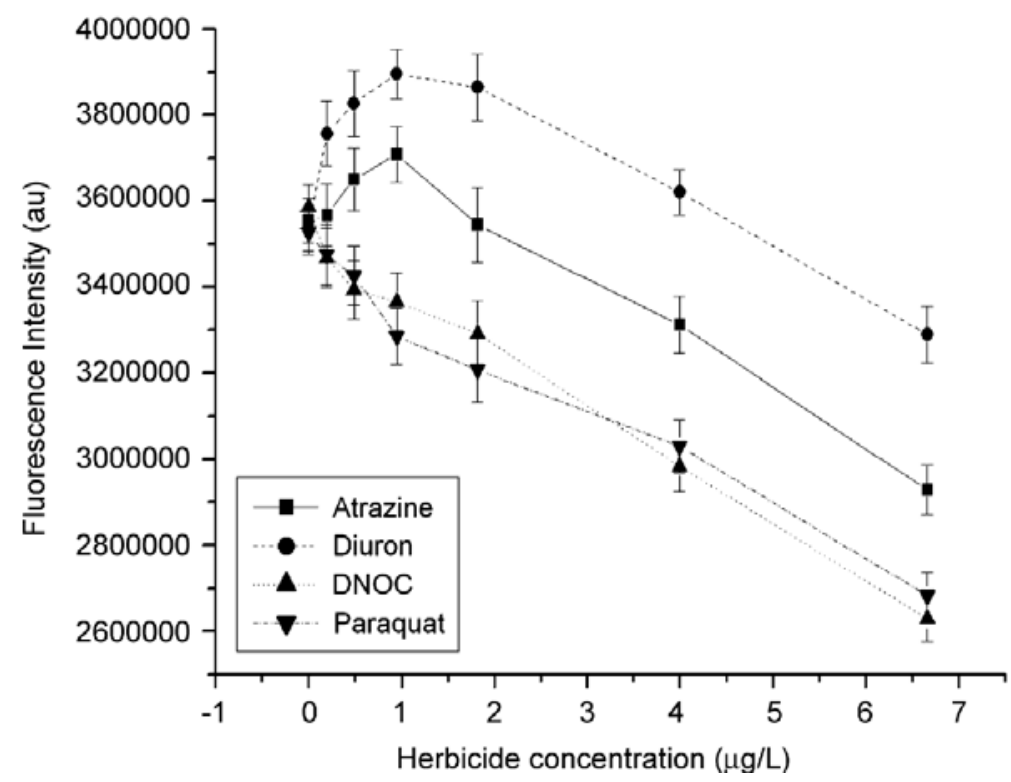

Fig 4:. Synchronous fluorescence of immobilized "C. vulgaris" cells $\left(35 \times 10^{6}\right.$ cells $\left./ \mathrm{mL}\right)$ as a function of herbicide concentration for various types of herbicides using $\Delta \lambda=20 \mathrm{~nm}$, and the fluorescence peak at $670 \mathrm{~nm}$ after $1 \mathrm{~h}$ contact time. Fluorescence intensity is expressed in arbitrary unit (au).

\section{Discussion}

In this work, synchronous-scan spectrofluorometry is used to assess the toxic effect of cadmium and herbicides on vegetal cells. It is known that cadmium has a toxic effect on bacteria, algae and fungi (Trevors et al., 1986; Singh and Tewari, 2003; Lin et al., 2007a, b) through its action on enzymes of the metabolic chain (Durrieu and Tran-Minh, 2002). 
Fig. 1 shows that it is also possible to use $\Delta \lambda=90 \mathrm{~nm}$ for $\mathrm{Cd}(\mathrm{II})$ toxicity testing, as adopted by Liu et al. (2005) for Fe(III) quenching, but the corresponding difference in fluorescence intensity is three times lower than with $\Delta \lambda=20 \mathrm{~nm}$ and consequently reduces the sensitivity of the technique. As indicated in the figure, the most appropriate $\Delta \lambda$ is $20 \mathrm{~nm}$ because it corresponds to the greatest reduction in fluorescence intensity in the presence of cadmium compared to all other wavelength differences. This is also the best $\Delta \lambda$ value for toxicity assessment, since it exhibits highest emission peak and good quenching efficiency with regard to the toxicant. For a same quenching efficiency, a greater fluorescence intensity is preferred for its higher signal-to-noise ratio.

In order to apply this technique to immobilized algal cells, a translucent matrix is required to minimize optical interference from the support. This has been obtained by entrapment of algal cells in a porous silica matrix using the sol-gel process (Nguyen-Ngoc and Tran-Minh, 2007a). Silica matrixes are relatively inexpensive to synthesize and have interesting properties, including optical transparency, biocompatibility and chemical inertness. This support also ensures algal suspension homogeneity and is suitable to produce fluorescent membranes for biosensors (Nguyen-Ngoc and Tran-Minh, 2007b).

Toxicity tests employing microalgae to determine the ecotoxic concentration of heavy metals provide important information for predicting the environmental impact of their pollution. Heavy metals are known to have a toxic effect on algal cells by inhibiting their growth (Lin et al., 2007a, b; ISO, 1998; ASTM, 1994). Cell counting, optical density and fluorescence measurements have been used for their growth quantification (Blaise et al., 1997). Synchronous-scan spectrofluorometry provides a new and rapid technique of direct ecotoxicological assessment of heavy metals from fluorescence quenching.

Herbicides play an important role in agricultural practices to control weeds and to avoid their competition with agricultural crops. An undesirable side effect of their use is that they may enter fresh water habitats and destroy nontarget species. Some are highly persistent and can be found in many environments such as soil, sediments and water (Field et al., 2003). Green algae C. vulgaris is very sensitive to herbicides (Ma et al., 2002) and its photosynthesis inhibition can be assessed from synchronous-scan fluorescence technique. A linear relationship is found between fluorescence intensity and concentration of the tested herbicides at concentrations higher than $1 \mu \mathrm{g} / \mathrm{L}$ : this could be applied to their determination in surface water. Since paraquat and DNOC are anti-PSI herbicides, they decrease the algal fluorescence intensity as usually reported (Fai et al., 2007) and confirmed in Fig. 4. Diuron and atrazine, known as PSII inhibitors, increase fluorescence emission as observed in Fig. 4 for low herbicide concentration. This change in fluorescence results from the specific mode of action of herbicides on algal photosystems in contrast to the simple negative physiological effect of growth inhibition. The growth inhibition actually results from various separate effects of toxic compounds on enzymes acting in sequence in the process of photosynthesis inhibition. Synchronous-scan spectrofluorometry experiments with other toxicants will help in providing evidence for discussion on the mode of action of those herbicides and their effect on fluorescence emission.

\section{Conclusion}

Synchronous-scan fluorometry can be effectively used to assess the sensitivity of $C$. vulgaris to heavy metals and herbicides. The wavelength difference $(\Delta \lambda)$ of $20 \mathrm{~nm}$ is optimal for characterization of the quenching effect of these toxic chemicals. On the whole, the higher the toxicant concentration, the greater the quenching efficiency. This result can be used for evaluation of toxic compounds after appropriate calibration. Such quantitative assays may be of interest for analytical purposes, as their concentration gives useful indications on their 
degree of photosynthetic inhibition. Atrazine and diuron exhibit a particular behavior which could be ascribed to their specific mode of action on PSII. The emission peak at $670 \mathrm{~nm}$, which is similar for both cells in suspension and immobilized in the silica support, facilitates the determination of toxicants in different media. The technique using algal cells immobilized in a translucent matrix is quite adapted to the construction of algal biosensors. The results are very useful since it demonstrates that synchronous-scan fluorometry could be a very sensitive technique for assessing the effects of toxicants on $C$. vulgaris at very low concentrations.

\section{Acknowledgments}

This work has been financially supported by Région Rhône-Alpes (MIRA fellowships and Thématiques Prioritaires program) and by CNRS (ACI program). No studies involving humans or experimental animals were conducted in this research.

\section{References}

Abou-Waly, H., Abou-Setta, M.M., Nigg, H.N., Mallory, L.L., 1991. Growth response of freshwater algae, Anabaena flos-aquae and Selenastrum capricornutum to atrazine and hexazinone herbicides. Bull. Environ. Contam. Toxicol. 46, 223-229.

ASTM (American Society for Testing and Materials), 1994. Standard Guide for Conducting Static 96-h Toxicity Tests with Microalgae. Annual Book of ASTM Standards. ASTM E1218-90. ASTM, Philadelphia, PA.

Blaise, C., Férard, J.F., Vasseur, P., 1997. Microplate toxicity tests with microalgae: a review. In: Wells, P.G., Lee, K., Blaise, C. (Eds.), Microscale Testing in Aquatic Toxicology. Advances, Techniques, and Practice. CRC Press, Boca Raton, FL, pp. 269-288.

Bozeman, J., Koopman, B., Bitton, G., 1989. Toxicity testing using immobilized algae. Aquatic Toxicology 14, 345-352.

Conrad, R., Buchel, C., Wilhelm, C., Arsalane, W., Berkaloff, C., Duval, J.C., 1993. Changes in yield of in vivo fluorescence of chlorophyll a as a tool for selective herbicide monitoring. J. Appl. Phycol. 5, 505-516.

Cosgrove, J., Borowitzka, M., 2006. Applying pulse amplitude modulation (PAM) fluorometry to microalgae suspensions: stirring potentially impacts fluorescence. Photosynth. Res. $88,343-350$.

Cowell, D.C., Dowman, A.A., Ashcroft, T., 1995. The detection and identification of metal and organic pollutants in potable water using enzyme assays suitable for sensor development. Biosensors Bioelectron. 10, 509-516.

Deng, N., Wu, F., Tao, S., Liu, X., Fang, T., Liu, J., 2005. Study on fluorescence emission and synchronous-scan fluorescence spectra of Nitzschia hantzschiana solution with Fe(III). Fresenius Environ. Bull. 14, 291-295.

Duarte, R.M.B.O., Pio, C.A., Duarte, A.C., 2004. Synchronous scan and excitationemission matrix fluorescence spectroscopy of water-soluble organic compounds in atmospheric aerosols. J. Atmos. Chem. 48, 157-171.

Durrieu, C., Tran-Minh, C., 2002. Optical algal biosensor using alkaline phosphatase for determination of heavy metals. Ecotoxicol. Environ. Saf. 51, 206-209.

Eullaffroy, P., Vernet, G., 2003. The F684/F735 chlorophyll fluorescence ratio: a potential tool for rapid detection and determination of herbicide phytotoxicity in algae. Water Res. 37 (9), 1983-1990.

Fai, P.B., Grant, A., Reid, B., 2007. Chlorophyll-a fluorescence as a biomarker for rapid toxicity assessment. Environ. Toxicol. Chem. 26 (7), 1520-1531. 
Field, J.A., Reed, R.L., Sawyer, T.E., Griffith, S.M., Wigington, P.J., 2003. Diuron occurrence and distribution in soil and surface and ground water associated with grass seed production. J. Environ. Qual. 32, 171-179.

Gard-Terech, A., Palla, J.C., 1986. Comparative kinetics study of the evolution of freshwater aquatic toxicity and biodegradability of linear and branched alkylbenzene sulfonates. Ecotoxicol. Environ. Saf. 12, 127-140.

Hou, X., Tong, X., Dong, W., Dong, C., Shuang, S., 2007. Synchronous fluorescence determination of human serum albumin with methyl blue as a fluorescence probe. Spectrochim. Acta Part A: Mol. Biomol. Spectrosc. 66, 552-556.

ISO (International Organization for Standardization), 1998. Water quality-guidance for algal growth inhibition tests with poorly soluble materials, volatile compounds, metals and wastewater, International Standard ISO/DIS 14442.

ISO 8692, 2002. Water quality-freshwater algal growth inhibition test with unicellular green algae. International Organization for Standardization, Geneva, Switzerland.

Jones, R.J., Kildea, T., Hoegh-Guldberg, 1999. PAM chlorophyll fluorometry: a new in situ technique for stress assessment in scleractinian corals, used to examine the effects of cyanide from cyanide fishing. Mar. Pollut. Bull. 38, 864-874.

Juneau, P., El Berdey, A., Popovic, R., 2002. PAM fluorometry in the determination of the sensitivity of chlorella vulgaris, Selenastrum capricornutum, and Chlamydomonas reinhardtii to copper. Arch. Environ. Contamin. Toxicol. 42, 155-164.

Kwan, K.K., 1989. Testing of coloured samples for toxicity by the algal-ATP bioassay microplate technique. Environ. Pollut. 60, 47-53.

Lin, K.C., Lee, Y.L., Chen, C.Y., 2007a. Metal toxicity to Chlorella pyrenoidosa assessed by a short-term continuous test. J. Hazard. Mater. 142, 236-241.

Lin, K.C., Lee, Y.L., Chen, C.Y., 2007b. Metal toxicity to Chlorella pyrenoidosa assessed by a short-term continuous test. J. Hazard. Mater. 142, 236-241.

Liu, X., Tao, S., Deng, N., 2005. Synchronous-scan fluorescence spectra of Chlorella vulgaris solution. Chemosphere 60, 1550-1554.

Lombardi, M.R., Lesser, M.P., Gorbunov, M.Y., 2000. Fast repetition rate (FRR) fluorometry: variability of chlorophyll a fluorescence yields in colonies of the corals, Montastraea faveolata and Diploria labyrinthiformes recovering from bleaching. J. Exp. Mar. Biol. Ecol. 252, 75-84.

Ma, J., Xu, L., Wang, S., Zheng, R., Jin, S., Huang, S., Huang, Y., 2002. Toxicity of 40 herbicides to the green alga Chlorella vulgaris. Ecotoxicol. Environ. Saf. 51,128-132.

Naessens, M., Leclerc, J.C., Tran-Minh, C., 2000. Fiber optic biosensor using Chlorella vulgaris for determination of toxic compounds. Ecotoxicol. Environ. Saf. 46,181-185.

Nguyen-Ngoc, H., Tran-Minh, C., 2007a. Sol-gel process for vegetal-cells encapsulation. Mater. Sci. Eng. C 27, 607-611.

Nguyen-Ngoc, H., Tran-Minh, C., 2007b. Fluorescent biosensor using whole cells in an inorganic translucent matrix. Anal. Chim. Acta 583, 161-165.

Oldham, P.B., McCarroll, M.E., McGown, L.B., Warner, I.M., 200o. Molecular fluorescence, phosphorescence, and chemiluminescence spectrometry. Anal. Chem. 72, 197R-209R.

Samson, G., Popovic, R., 1988. Use of algal fluorescence for determination of phytotoxicity of heavy metals and pesticides as environmental pollutants. Ecotoxicol. Environ. Saf. 16, 272-278.

Sikorska, E., Go' recki, T., Khmelinskii, I.V., Sikorski, M., Kozio, J., 2005. Classification of edible oils using synchronous scanning fluorescence spectroscopy. Food Chem. 89, 217225 . 
Singh, P.K., Tewari, R.K., 2003. Cadmium toxicity induced changes in plant water relations and oxidative metabolism of Brassica juncea L. plants. J. Environ. Biol. 241, 107-112.

Tomulka, K.W., Mac Gee, D.J., Lange, J.H., 1993. Use of the bioluminescent bacterium Photobacterium phosphoreum to detect potentially biohazardous materials in water. Bull. Environ. Contam. Toxicol. 51, 538-544.

Trevors, J.T., Stratton, G.W., Gadd, G.M., 1986. Cadmium transport, resistance, and toxicity in bacteria, algae, and fungi. Can. J. Microbiol. 32, 447-464.

Von Emon, J.M., Lopez Avilla, V., 1992. Immunochemical methods for environmental analysis. Anal. Chem. 64, 79-88.

Wang, L., Chen, H., Wang, L., Wang, G., Li, L., Xu, F., 2004. Determination of proteins at nanogram levels by synchronous fluorescence scan technique with a novel composite nanoparticle as a fluorescence probe. Spectrochim. Acta Part A: Molec. Biomolec. Spectrosc. 60, 2469-2473. 